\title{
MÜHELYTITKOK
}

\section{DRÓTH JÚLIA \\ Fordítási stratégiák az elméletben és a fordítástechnika oktatásában}

Bár a forditási stratégia kifejezés számos fordításelméleti és oktatási modell része, értelmezése és alkalmazása bizonytalan: utalhat folyamatra, eredményre, technikákra, módszerekre, eljárásokra, átváltásokra, mủveletekre. Írásomban áttekintem a stratégia fogalmát, főbb típusait, valamint szerepét a fordítástechnika oktatásában. Célszerü a fordítási stratégiákat olyan módszerként kezelni, amelynek segítségével a fordító alkalmazkodik a fordítási normákhoz a lehető legjobb célnyelvi változatok érdekében. A stratégiáknak ez az alkalmazása megegyezik a fordítástechnika tantárgy céljaival. A tananyag fordítási feladatokra épül, s a makroszintü fordítói döntések elökészítésével kezdődik. Ugyanakkor a hallgatók a mikroszintü döntéseikkel kapcsolatban is folyamatos visszajelzést kapnak a fordításaik lektorálásán, értékelésén keresztül. Ez lehetővé teszi, hogy az elméletet összekapcsoljuk a gyakorlattal, és a tanulóktól érkező kérdések nagy arányban szerepeljenek az órai témák között.

Kulcsszavak: fordítási stratégia, fordítási modellek, fordítási normák, fordítástechnika, oktatás

\section{Bevezetés}

A fordításoktatás dokumentumainak készítésekor (tanmenetek, tantervek, tantárgyleírások, szakleírások stb.) gyakori elvárás a fejleszteni kívánt fordítási stratégiák ismertetése. Bár az utóbbi években szakmai napunkon (Károli Gáspár Református Egyetem, 2018. január) és az ott elhangzott előadások írásbeli változatainak közlésével (Modern Nyelvoktatás, 2018. 2-3.) igyekeztünk tisztázni a fordítási stratégia fogalmát, ma is gondot okoz a fogalom értelmezése és alkalmazása. Ezért az alábbiakban áttekintem a stratégia fogalmát, típusait, valamint szerepét a fordítástechnika oktatásában általában és a Károli Gáspár Református Egyetem egyik fordítástechnika kurzusának gyakorlatában.

\section{A fordítási stratégia jelentései, funkciói}

A forditási stratégia kifejezés számos fordításelméleti és oktatási modell része, ennek ellenére nem könnyü meghatározni a jelentését. A fordítási stratégiák számbavétele és kritikája, újabbak megfogalmazása fél évszázada zajlik a fordítástudományban (például Nida, 1964; Catford, 1965; Chesterman, 2005; Vinay \& Darbelnet, 1995; Klaudy, 1999a, b; Pym, 2013).

Úgy tünik, a fordítási stratégia mint terminus nem tölti be a terminusoktól elvárt két alapvető funkciót: az adott szakterületen belül mindig ugyanazt jelentse, és ne utaljon több, egymástól különbözö tartalomra. Márpedig a forditási stratégia kifejezés utalhat 
folyamatra, eredményre, technikákra, módszerekre, eljárásokra, átváltásokra, műveletekre. (A pedagógiai szövegekben általában nehézséget jelent a stratégia szó definiálása, ezért például különböző értelmezései vannak a stratégiák fejlesztésének, lásd az idegennyelv-tanítási dokumentumokat [Einhorn Ágnes személyes közlése, 2021]. Ezt a terminológiai zavart érintette a Károli Gáspár Református Egyetemen 2018-ban rendezett konferencia, az előadások írásbeli változatát a Modern Nyelvoktatás 2018-as fordítástudományi különszámában közöltük (Modern Nyelvoktatás, 2018. 2-3.).

A fordítási stratégia terminus alkalmazásának másik problémájáról is hallhattunk ezen a konferencián: „A »stratégia« használatában gyakran összemosódnak az automatikus és a tudatos müveletek, pedig a »stratégia« terminust inkább a tudatos müveleteknek kellene fenntartani” (Klaudy, 2018, p. 12).

Hasonló bírálatot olvashatunk Chestermantól is: a fordítási stratégia kifejezés terminusként problémás: különböző dolgokra utal a fordítástudományban, és máshogyan is ki lehet azokat fejezni. Következetlen a fordítási stratégia kifejezés alkalmazása abban is, hogy a folyamatra és az eredményre egyaránt utal (procedural és textual strategies) (Chesterman, 2005, p. 20).

A fordítási stratégia egyik jelentése a fordítás folyamatában jelentkező problémák megoldásához alkalmazott tudatos lépések sorozata (Lörscher, 1991, p. 76 alapján, idézi Kovalik-Deák, 2020, p. 92). A tudatos problémamegoldás számos fordítástechnikai kérdést érint. Vonatkozhat például a fordítói háttérkutatásokhoz kapcsolódó fordítói döntésekre, az etikai kérdésekre, a kezdő és a tapasztalt fordítók stratégiája közötti különbségekre, a forrásnyelvi kulturális jegyek közelítésére a célnyelvi kultúrához, az ehhez és más problémákhoz kapcsolódó fordítási műveletekre vagy - egyebek mellett - a problémamegoldó kompetenciára. Az alábbiakban ezeket a stratégiákat veszem sorra.

Nem könnyủ valós képet kapni a fordítók problémamegoldó stratégiáiról. Számos pszicholingvisztikai eszközökre épülö kutatás igyekszik feltárni, mi történik a fordító fejében fordítás közben, milyen stratégiákat alkalmaz. A kutatók közvetett adatokra támaszkodnak, melyeket a körülmények különféleképpen torzíthatnak (ilyen például a think aloud protocol [TAP], Jääskeläinen, 2009). A számítógépes eszközök révén azonban egyre pontosabbá válnak ezek a felmérések.

A problémamegoldó stratégiák közé tartoznak a forditási hibák etikus elkerülésére javasolt technikák, például:

- Nem szabad elfelednünk, hogy bármikor tévedhetünk. (Ne féljünk a tévedéstől!)

- Hagyatkozzunk a rajtunk kívül álló kompetenciákra (például fogadjuk el egy terület kialakult nyelvezetét)!

- Ha a szükséges információt semmiképp sem tudjuk felkutatni, hagyjuk ki a szót, amennyiben van erre lehetőség.

- Ha más megoldás nincs, valljuk be, hogy nem találtuk meg a hiányzó megnevezést.

- Ha nem ismert a fordított szöveg funkciója, készítsünk két ajánlható megoldást (ne többet), és írjuk le a köztük lévő különbséget (Pym, 1993, pp.134-139).

Ez a rövid „életmentő” lista természetesen arra is utal, hogy a tudatos stratégiák mellett nagy szerepük van a nyelvi-forditási szabályok ismeretének, valamint a fordítói munka elvégzéséhez szükséges alapvető szakmai-etikai normáknak. Göpferich (2009, 
p. 23) szerint az utóbbiak három tényezőből állnak: 1. fordítási utasítás és normák (ahogy a szakma elvárja, például szabványok és szabályok [például az idézetek kezelése]) figyelembevétele, 2 . a fordító önmagáról alkotott képe, társadalmi felelősségvállalási képessége, 3. a fordító fizikai-pszichológiai állapota (intelligenciája, kitartása stb.).

A fordítás folyamatát illetően számos kutatás rámutat arra a stratégiai különbségre, amely a kezdő és a tapasztalt fordítók figyelmét jellemzi: míg a kezdő fordítók lexikai és más nyelvi részletekre fókuszáló, lokális, azaz mikroszintü döntésekkel haladnak a fordítás folyamatában, addig a gyakorlott fordítók a forrásnyelvi szöveg bizonyos szempontjait kiemelö globális, makroszintü döntéseket hoznak a fordítás előtt, és ezeket a teljes fordítási folyamatban érvényesítik (Tirkkonen-Condit, 1996, p. 254).

A makroszintủ stratégiák egyik kiemelkedő, más stratégiákat is meghatározó csoportja (saját szóhasználattal élve) a forditás típusa, amely a forrásnyelvi kultúra és a célnyelvi közönség igényei közötti viszonyt tükrözi. A fordítástudomány szakemberei számos fogalompárt hoztak létre, hogy megnevezzék ennek a viszonynak a két végpontját: idegenítő-honosító, nyílt-rejtett (House, 1997), dokumentum jellegü-instrumentális (Nord, 1997), szemantikai-kommunikatív (Newmark, 1981), direkt-indirekt (Gutt, 1991) fordítás.

A forditási stratégia terminus egy viszonylag újabb használata kiterjed a célnyelvi szövegben megfigyelhető fordítási átváltásokra, müveletekre, eljárásokra is. Idetartozik például Klaudy átváltási mủveleteinek rendszere (1994), valamint Pym fordítási eljárásainak sora (2016). Ezek megfigyelése, megnevezése, esetleges szabályszerüségek levonása hasznos módszere a fordítástechnika óráknak, megerősíti a fordító döntési képességét olykor a makro-, de föleg a mikroszintü kérdésekben.

Ha fordításoktatásról és ezen belül a tananyag kialakításáról van szó, említést kell tennünk a fordítási kompetenciákról is, hiszen a kutatások egy része (például PACTE, 2005; Göpferich, 2009) fordításikompetencia-modelljében az ún. stratégiai kompetenciát állítja középpontba, mely nem más, mint a fordítás folyamatában felmerülö problémák megoldását szolgáló eljárások összessége.

Az EMT (European Master's in Translation, Competence Framework, 2017) szintén elméleti és gyakorlati kutatások eredményeképpen állította össze a mesterképzések képzési-kimeneti követelményeit, s ebben a kialakítandó fordítási kompetenciák listáját: nyelvi és kulturális, fordítási, technológiai, személyes és interperszonális, illetve mindezek középpontjában a szolgáltatói kompetencia. Ezen belül minden egyes kompetenciát elláttak a képességek és ismeretek részletes felsorolásával is. Ezek között az alkompetenciák között gyakran találkozunk a stratégia vagy stratégiai kifejezéssel. Így a fordítási kompetencia lehet stratégiai, módszertani és tematikus kompetencia, és itt olvashatunk a megfelelő célnyelvi megfogalmazáshoz szükséges stratégiákról és a minőség-ellenőrzési stratégiákról is; a személyes és interperszonális kompetencia alá tartoznak az egyéni tanulási stratégiák; a szolgáltatási kompetencia alatt pedig kiemelik a marketing stratégiák és fejlesztési stratégiák szerepét is (EMT, 2017).

Célszerünek tủnik tehát a fordítási stratégiát szinte gyüjtőfogalomként kezelni. Chesterman definíciója szerint ,a stratégia olyan módszer, melynek segítségével a fordító alkalmazkodik a fordítási normákhoz [...] az általuk elérhető lehető legjobb változatok érdekében". Ezt az alkalmazkodást Chesterman szerint kétféle stratégiával valósíthatjuk meg: a forrásnyelvi szöveg megértését szolgáló stratégiák és a célnyelvi 
szöveg létrehozását szolgáló stratégiák alkalmazásával. Az utóbbiakat oktatási célból sokan kutatják, és három alcsoportba sorolhatóak: 1. szintaktikai, 2. szemantikai és 3. a célnyelvi olvasóközönség igényeit figyelembe vevő pragmatikai stratégiák (1997, p. 88, idézi Baker \& Saldanha, 2011, p. 285).

Ezek azok a stratégiák, melyek oktatása megegyezik a fordítástechnika tantárgy céljaival, s melyeket a kialakított tananyagunk és hibatipológiánk is tükröz.

\section{A fordítástechnika tantárgy célja és módszerei}

A Károli Gáspár Református Egyetem szakfordító és műfordító szakirányú továbbképzésén oktatott fordítástechnika nevü egyféléves, bevezető jellegü tantárgy célja, hogy elősegítse a megfelelő fordítási stratégiák kialakítását. Ezt a törekvést a tananyag és annak felépítése egyaránt tükrözi: bemutatja a fordítás folyamatát, a fordítói gondolkodás sarokköveit, a fordítás elökészítéséhez és a háttérkutatásokhoz szükséges stratégiákat, eszközöket, a fordítási normákat, ismereteket, hagyományokat, és fejleszti a fordításhoz szükséges készségeket. A hallgatók problémamegoldó stratégiáját úgy fejlesztjük, hogy támpontokat adunk a fordítói gondolkodáshoz és a tudatos döntésekhez. Ráirányítjuk a hallgatók figyelmét a problémamegoldás folyamatára, a választási lehetőségekre és az etikus hozzáállásra.

Ezeket a célokat legjobban az induktív módszerek szolgálják. Ennek kulcsa a szövegválasztás: olyan forrásnyelvi szövegek fordíttatása, amelyekben fejtörést okoznak a fordítási folyamat soron következő lépései, kérdéseket ébresztenek a hallgatókban, és döntés elé állítják őket. Az ilyen órai vagy házi feladat elkészítése és tanári (és/vagy csoporttársi) lektorálás után élénk megbeszélés zajlik, mely során kikristályosodnak a megfelelö eljárások, módszerek, stratégiák, gyarapodnak a fordításhoz szükséges ismeretek és képességek. A módszer lényegéhez tartozik, hogy a megbeszélést megelőzően sor kerüljön a fordítások írásbeli lektorálására, formatív értékelésére (azaz a rendszeres visszajelzésre a hibákról és jó megoldásokról); a megbeszélés során pedig elvégezzük a célnyelvi szöveg javítását is.

A tantárgy oktatásának egyik fó célja, hogy a hallgatók választ kapjanak arra a gyakori stratégiai kérdésükre, mi alapján dönthetik el, melyik célnyelvi megoldást válasszák egy-egy szöveg vagy fordítási egység lefordítására. Anthony Pym ezt így fogalmazza meg, amikor a fordítási kompetencia lényegéről ír: a fordítási kompetencia két készségből tevődik össze: 1 . a forrásnyelvi szöveg fordításaként több célnyelvi variáció létrehozásának képessége; 2. e variációkból egyetlen célnyelvi szöveg gyors és megalapozott kiválasztásának képessége a célnyelvi szöveg céljának és olvasójának megfelelöen (Pym, 1992, p. 281).

Pym tehát úgy véli, hogy a fordító fejében egy adott forrásnyelvi szöveg kapcsán több célnyelvi megfelelő merül fel (más megközelítésben ez az asszociatív kompetencia [Hönig, 1991, idézi Kovalik-Deák, 2020, p. 11]). Ezekböl a fordító tudatos döntések révén kiválasztja az egyetlen lehetséges célnyelvi változatot (stratégiai kompetencia). Ehhez a tudatos döntéshez szükség van a kommunikációs helyzet, a fordítási feladat előzetes elemzésére (a forrásnyelvi szöveg megjelenési helye, ideje, funkciója, múfaja, a célnyelvi szöveg megjelenési helye, ideje, a fordítás funkciója, célközönsége, a téma, szakterület ismerete, háttérkutatások lehetséges módja [hasonlóképpen lásd Nord, 1997]) és az adott helyzetnek megfelelő makro- és mikrostratégiák alkalmazására. 
A Pym által leírt fordítási kompetencia kialakításának feltétele, hogy tudjuk, mit is nevezünk megfelelö fordításnak, mi a fordítás célja. A fordítástechnika órák gyakorlati munkájában számunkra Heltai Pál definíciója bizonyult a leginkább célravezetőnek. Eszerint a fordítás egy már létező, verbális formában kifejezett üzenet megismétlése egy másik nyelven, teljesen más formában. A fordítás célja, hogy az üzenet tartalma és funkciója [a célközönség számára] hozzáférhetővé váljon (Heltai, 2014, pp. 282-283).

Pym és Heltai meghatározásának értelmében tehát a fordítónak meg kell ragadnia az üzenet lényegét (globális szempont), és az írói szándéknak megfelelően (globális szempont), valamint a célnyelvi olvasó igényeihez alkalmazkodva (globális szempont) meg kell ismételnie ezt az üzenetet a másik nyelven úgy, hogy a szöveg minden elemében hozzáférhető, jól értelmezhető legyen (lokális szempont).

\section{A fordítástechnika tantárgyban oktatott stratégiák}

A tantárgy fent leírt céljainak megfelelöen a föbb makrostratégiai döntések a szövegtípusra, az írói szándékra, a müfajra, a regiszterre és a reáliák kezelését is meghatározó fordítási típusra vonatkoznak. Ez utóbbiba olyan fogalompárok tartoznak, mint a már említett idegenítő-honosító fordítás.

A megfelelő célnyelvi elemek kialakítása viszont már a célnyelvi lexikai és grammatikai hagyományokat, bizonyos szabályokat is érint. A tapasztalat azt mutatja, hogy számukat, arányukat tekintve leginkább ezek a lokális hibák fordulnak elő a hallgatók fordításaiban, ezeket javítjuk leggyakrabban. Ezekről a formatív értékelés során feltétlenül és sokszor visszajelzést adunk, így ezek a mikroszintü szempontok is elötérbe kerülnek. Mindezen keresztül érvényesül az oktatásban a makro- és mikroszintủ gondolkodás, stratégia.

Annak érdekében tehát, hogy a Pym és Heltai definíciójában megfogalmazott értelmezés, döntés és célnyelvi megvalósítás létrejöhessen, jó, ha a fordítástechnika oktatását egy időben két irányból végezzük: egyrészt a globális elemzéstől és a hozzá szükséges elméleti megfontolásoktól, másrészt a fordítási folyamat során felmerülő lokális kérdésektől kezdjük. Ez utóbbiak a globális és analitikus szempontok alapján végzett formatív értékelés átbeszélésekor, a fordítási folyamat és a célnyelvi szövegek órai megbeszélése során kerülnek felszínre, a félév végén pedig tételesen tárgyaljuk őket.

A fordítást megelőző globális elemzés során a hallgatók képet alkotnak a szöveg főbb, a fordítás szempontjából fontos pragmatikai és szövegtani jellemzőiröl: a forrásnyelvi és célnyelvi szöveg megjelenési helyéről, idejéről, a célnyelvi szöveg olvasójáról, a szöveg retorikai céljáról, szövegtípusáról, múfajáról, regiszteréről. Ezek a szempontok meghatározzák a fordító szövegtani, lexikai, grammatikai döntéseinek nagy részét. A szöveg globális elemzését az órán az előzetes elemzésben rögzítjük, és a továbbiakban minden fordítás előtt elvégezzük. Az ismereteket és az elemzési készséget pedig különféle gyüjtőmunkával, megfigyelésekkel, összevetésekkel bővítjük, mélyítjük el, visszük közelebb a gyakorlathoz.

A tananyag tehát fordítási feladatokra épül, s a makroszintü fordítói döntések előkészítésével kezdődik. Ugyanakkor a hallgatók a mikroszintű döntéseikkel kapcsolatban is folyamatos visszajelzést kapnak a fordításaik javításán, lektorálásán, értékelésén keresztül. Célszerü olyan szövegeket és fordítási helyzeteket választani, amelyek felvetik az épp tárgyalt globális fordítástechnikai kérdéseket (például az adott szöveg 
regiszterének sajátosságait), így gyakorlati jellegủ és egyben motiváló a feladat. A célnyelvi szöveg megfogalmazása ugyanakkor előhoz lokális fordítástechnikai kérdéseket is (például a regiszternek és a tárgyi ismereteknek megfelelő lexikai/terminológiai, grammatikai, valamint kohéziós eszközök megválasztását).

Napjainkban a szakfordítás oktatásának figyelembe kell vennie a piaci elvárások gyors átalakulását, melynek következtében megváltozik a fordító szerepe és az általa alkalmazott fordítási stratégia is. Ma már nem a rejtett fordítási stratégia az elsődleges, a fordító nyíltan felvállalja a kultúrák közötti közvetítést: szükség esetén adaptál, magyaráz, kiegészít, hangsúlyt változtat (Pym, 2016, p. 262). Ugyanakkor a honosító fordítási stratégiával szemben gyakran az idegenítő stratégia kerül előtérbe: a fordító épít a nyelvi sokféleség és az interferencia jelenlétére, maguk a többnyelvü fordítók is ennek a nyelvi világnak a szülöttjei.

Végezetül felsorolom a félév tematikájának címszavait az oktatás sorrendjében: a fordítás fogalma, célja és fajtái; fordíthatóság; a fordítás stratégái; a fordítás folyamata; a háttérkutatás eszközei; szövegtípus; írói szándék (retorikai cél); müfaj; regiszter; szaknyelvi szövegek fordítása és terminológia; reáliák és lexikai mủveletek; kohézió és grammatikai müveletek, illetve a hozzájuk kapcsolódó normák és szabályok.

\section{Összegzés: az elmélet és gyakorlat egységét szolgáló stratégiák}

A globális döntésekre épülö, illetve a fordítási feladat lokális kérdéseiből kiinduló stratégia együttes alkalmazása lehetővé teszi, hogy az elméletet összekapcsoljuk a gyakorlattal, és ne csupán az elméleti kérdések határozzák meg a tananyagot, hanem a tanulóktól érkező gyakorlati kérdések is nagy arányban szerepeljenek az órai témák között. További előnye a módszernek, hogy a tanár által adott globális és lokális fordítástechnikai útmutatások kiegészülnek a tanulók által felvetett kérdésekkel, a közösen kialakított javaslatokkal. Ezt a mozzanatot támogatja a formatív értékelés a folyamatos visszajelzéseken keresztül.

Akkor teljes a kommunikáció, ha a célnyelvi szöveg megfelel a célnyelvi olvasó elvárásainak. Ezért a fordítást oktató tanárok nem csupán arra törekednek, hogy hallgatóik pontosan közvetítsék az üzenetet, hanem arra is, hogy a célnyelvi olvasó számára ne jelentsen a szükségesnél nagyobb erőfeszítést a szöveg befogadása. Az oktatás igyekszik célszerü fordítási stratégiákat ajánlani a célnyelvi hagyományoknak megfelelő fordítások létrehozására.

\section{IRODALOM}

Baker, M. \& Saldanha, G. (2011, Eds.). Routledge Encyclopedia of Translation Studies. Routledge.

Catford, J. C. (1965). A Linguistic Theory of Translation. An Essay in Applied Linguistics. Longman.

Chesterman, A. (1997). Memes of Translation: The Spread of Ideas in Translation Theory. John Benjamins. https://doi.org/10.1075/btl.22

Chesterman, A. (2005). Problems with Strategies. In Károly, K. \& Fóris, Á. (Eds.), New Trends in Translation Studies (pp. 17-28). Akadémiai Kiadó. https://doi.org/10.1075/target.17.1.12che

EMT (2017). European Master's in Translation Competence Framework 2017. https://ec.europa.eu/info/ sites/info/files/emt_competence_fwk_2017_en_web.pdf(2021.08.04.) 
Göpferich, S. (2009). Towards a model of translation competence and its acquisition: the longitudinal study TransComp1. http://gams.uni-graz.at/fedora/get/o:tc-095-187/bdef:PDF/get. (2021.04.06.)

Gutt, E.-A. (1991). Translation and Relevance. Cognition and Context. Basil Blackwell.

Heltai P. (2014). Mitól forditás a forditás? Eötvös József Könyvkiadó.

Hönig, H. G. (1991). Holmes 'Mapping Theory' and the landscape of mental translation processes. In Van Leuven-Zwart, K. \& Naajkens, T. (Eds), Translation Studies: The State of the Art. Proceedings from the First James S. Holmes Symposium on Translation Studies (pp. 77-89). Rodopi. https://oi. org/10.1163/9789004488106_010

House, J. (1997). Translation Quality Assessment: A Model Revisited. Narr Verlag.

Jääskeläinen, R. (2009). Think-aloud Protocols. In Baker, M. \& Saldanha, G. (Eds.), Routledge Encyclopedia of Translation Studies (pp. 290-293). Routledge.

Klaudy K. (1994). A forditás elmélete és gyakorlata. Angol, német, francia, orosz forditástechnikai példatárral. Scholastica.

Klaudy K. (1999a). Bevezetés a forditás elméletébe. Scholastica.

Klaudy K. (1999b). Bevezetés a forditás gyakorlatába. Angol, német és orosz forditástechnikai példatárral. Scholastica.

Klaudy, K. (2018). Az átváltási mủveletek rendszere. Modern Nyelvoktatás, 24(2-3), 5-15.

Kovalik-Deák, Sz. (2020). Forditóhallgatók C nyelvi szókincsének asszociatív kapcsolatai a fordítói döntések hátterében. (Kiadatlan doktori disszertáció). ELTE BTK Nyelvtudományi Doktori Iskola, Fordítástudományi Doktori Program.

Lörscher, W. (1991). Translation Performance, Translation Process, and Translation Strategies. A Psycholinguistic Investigation. G. Narr Verlag.

Modern Nyelvoktatás, 2018. 2-3. (Fordítástudományi különszám, vendégszerkesztő: Dróth J.)

Newmark, P. (1981). Approaches to Translation. Pergamon.

Nida, E. A. (1964). Towards a Science of Translating: With Special Reference to Principles and Procedures Involved in Bible Translating. Brill. https://doi.org/10.1163/9789004495746

Nord, C. (1997). Translating as a purposeful Activity. Functionalist Approaches Explained. St. Jerome Publishing.

PACTE group. (2005). Investigating Translation Competence: Conceptual and Methodological Issues. Meta, 50(2), 609-619. https://doi.org/10.7202/011004ar

Pym, A. (1992). Translation error analysis and the interface with language teaching. In Dollerup, C. \& Loddegard (Eds.), Teaching translation and Interpreting. Training, Talent and Experience (pp. 279-290). Benjamins. https://doi.org/10.1075/z.56.42pym

Pym, A. (1993). Epistemological Problems in Translation and Its Teaching. Edicions Caminade.

Pym, A. (2013). Translation skill-sets in a machine-translation age. Meta, 58(3), 487-503. https://doi. org/10.7202/1025047ar

Pym, A. (2016). Translation solutions for many languages. Histories of a flawed dream. Bloomsbury Academic.

Tirkkonen-Condit, S. (1996). What Is in the Black Box? Professionality in Translational Decisions in the Light of TAP Research. In Lauer, A. et al. (Eds.) Überzetsungswissenschaft im Umbruch: Festschrift für Wolfram Wills zum 70 Geburtstag (pp. 251-257). Narr Verlag.

Vinay, J. P. \& Darbelnet J. ([1958] 1995). Comparative Stylistics of French and English. A methodology for Translation. John Benjamins. https://doi.org/10.1075/btl.11 


\section{Translation strategies in theory and in teaching translation techniques}

Although the term translation strategy forms part of many models of translation theory and education, its meaning and application are ambiguous: it can refer to process, outcome, techniques, methods, procedures, shifts and operations. In this paper, we will review the main types of strategy and its role in the teaching of translation techniques. It is useful to think of translation strategies as a method by which the translator adapts to translation norms in order to produce the best possible target language version. This interpretation of the strategies is in line with the objectives of our translation techniques topic. The course is based on translation tasks and starts with the preparation of macrolevel translation decisions. At the same time, students receive continuous feedback on their microlevel decisions through the proofreading and evaluation of their translations. This allows theory to be combined with practice, and students' questions to be incorporated into the course material.

Keywords: translation strategy, translation models, translation norms, translation technique, education 